\title{
Characteristics of the Healthcare Workers Infected with the COVID-19 Virus After Receiving the First Dose of Coronavirus Vaccine
}

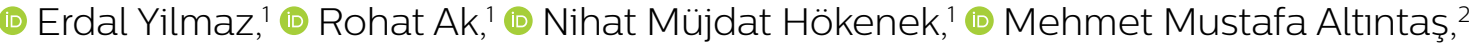 \\ (1) Ayse Batirel, ${ }^{3}$ (D) Recep Demirhan ${ }^{4}$
}

\section{'Department of Emergency Medicine, University of Health Sciences, Kartal Dr. Lütfi Kırdar City Hospital, İstanbul, Turkey 2Department of General Surgery, University of Health Sciences, Kartal Dr. Lütfi Kırdar City Hospital, İstanbul, Turkey \\ ${ }^{3}$ Department of Infectious Disease and Clinical Microbiology, University of Health Sciences, Kartal Dr. Lütf Kırdar City Hospital, İstanbul, Turkey ${ }^{4}$ Department of Thoracic Surgery, University of Health Sciences, Kartal Dr. Lütfi Kırdar City Hospital, İstanbul, Turkey}

Submitted: 25.03 .2021 Accepted: 06.05.2021

Correspondence: Rohat Ak Sağlık Bilimleri Üniversitesi, Kartal Dr. Lütfi Kırdar Şehir Hastanesi, Acil Tıp Anabilim Dalı, İstanbul, Turkey

E-mail: rohatakmd@gmail.com

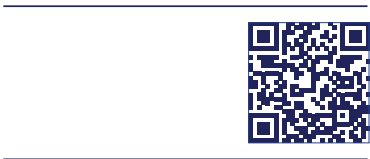

Keywords: CoronaVac; COVID-19; healthcare workers; vaccination; vaccine.

\begin{abstract}
Objective: Healthcare workers (HCWs) are at higher risk of COVID-19 infection. As in many countries, priority has been given to the vaccination of healthcare in Turkey. Our aim in the present study is to examine healthcare workers who contracted COVID-19 infection after receiving the first dose of the CoronaVac vaccine in our hospital.
\end{abstract}

Methods: In this retrospective observational study, the first dose of the CoronaVac vaccine was administered to healthcare workers in our hospital on January 14, 2021. All healthcare workers of both sexes, who were confirmed to have COVID-19 infection by RT-PCR test in the one-month post-vaccination period, were included in the study. The patients' demographics and general clinical data were analysed using the hospital's electronic patient record management system (EPRMS).

Results: There are 4,195 healthcare workers in our hospital. Of these, $3,259(77.68 \%)$ received the first dose of the CoronaVac vaccine. Of all healthcare workers diagnosed with COVID-I 9 infection, $17(56.7 \%)$ were female and I 3 (43.3\%) were male, with an average of $38.96 \pm$ I I. 23 years. Two patients were admitted to the pandemic service. None of the patients were admitted to the intensive care unit or died.

Conclusion: Undetected cases of COVID-19, especially among healthcare workers, can be dangerous for patients and other healthcare workers. Therefore, vaccination of all healthcare workers should be the primary goal. It should always be kept in mind that even if vaccinated, it is possible to become infected with COVID-19, and thus, personal protective measures should always be maintained in the fight against the disease. The occurrence of COVID-19 cases after the first dose of the.

\section{INTRODUCTION}

The novel coronavirus disease 2019 (COVID-19) caused by the severe acute respiratory syndrome coronavirus 2 (SARS-CoV-2), has become a pandemic, leading to high morbidity and mortality worldwide. ${ }^{[1,2]}$ As of March I, 2020, COVID- 19 has caused more than 113 million confirmed cases and more than 2.5 million deaths worldwide. ${ }^{[3]}$ Healthcare workers, the elderly (over 60 years of age), and those with underlying health problems are at particularly high risk. ${ }^{[4,5]}$

By the end of 2020, several vaccines have become available in different parts of the world, and more than 40 candidate vaccines are in human trials, and more than 150 are still under investigation in preclinical trials. ${ }^{\left[{ }^{6}\right]}$ Healthcare workers have been given priority in many countries for the administration of the available vaccines. ${ }^{[7]}$ 
The CoronaVac (Sinovac Life Sciences, Beijing, China) vaccine developed in China is an inactivated vaccine used for COVID-19. The vaccine is injected intramuscularly as two doses in 28 days apart. Phase studies indicated CoronaVac to be safe and immunogenic. ${ }^{[8,9]}$ This vaccine has started to be widely used in many countries, including Turkey. Our aim in the present study is to examine healthcare workers who contracted COVID-19 infection after receiving the first dose of CoronaVac vaccine in our hospital.

\section{MATERIALS AND METHODS}

This retrospective observational study was carried out at the Kartal Dr. Lütfi Kırdar City Hospital between January 14, 2021 and February 14, 2021. The institutional review board approved the analysis and issued a waiver of consent (Ethics Committee Ruling number: 514/196/26).

Kartal Dr. Lütfi Kırdar City Hospital, located in the east of Istanbul, is a healthcare centre that diagnoses and treats approximately 3 million patients annually with 97I wards and 224 intensive care beds. In the first I year of the pandemic, that is, from March II, 2020, when the first case of COVID-1 9 was confirmed in Turkey, to February 2021, a total of 322,390 outpatients, 7,0I 5 inpatients, and I,286 intensive care patients with COVID-19 were diagnosed and received treatment at our hospital.The first dose of the CoronaVac vaccine was administered to healthcare workers at the Kartal Dr. Lütfi Kırdar City Hospital on January 14, 2021. All healthcare workers of both sexes who were confirmed to have COVID-19 infection by RTPCR test after vaccination were included in the study. ${ }^{[10]}$ The patients' demographic and general clinical data were analysed using our hospital's electronic patient record management system (EPRMS).

Statistical analysis was conducted using the SPSS version 21.0 for Windows and MedCalc. Descriptive analyses were performed for patient data and frequency ratios were measured. Descriptive statistics are given as average and standard deviation, median and minimum-maximum, and percentage distribution. The normality of population distribution was confirmed using the Shapiro-Wilk test.

\section{RESULTS}

A total of 4,195 healthcare workers work at the Kartal Dr. Lütfi Kırdar City Hospital. There are 25 different vaccination units in the Vaccine Application Centre established within the hospital, and the first dose of CoronaVac vaccine was administered to 3,259 (77.68\%) healthcare workers within four days as of January 14, 2021. After receiving the first dose of vaccine, 30 healthcare workers were diagnosed with PCR-confirmed COVID-19. No pointsource exposure associated with the vaccination process was identified in the surveillance analysis. Of all healthcare workers diagnosed with COVID-19 infection, 17 (56.7\%) were female and 13 (43.3\%) were male, with a average age of $38.96 \pm$ I I .23 years. It was revealed that $23(76.7 \%)$ of these COVID-19-positive HCWs had PCR test as they had typical COVID-19 symptoms (cough, fever, weakness, joint pain), 5 had suspected close contact, and 2 for confirming they have good health to attend the hospital.

Complaints started at $13.33 \pm 8.48$ days and PCR positivity was detected $13.03 \pm 8.45$ days after vaccination. Getting tested as soon as the complaints began indicates that there is still a high suspicion for COVID-19 even during the vaccination process. The PCR became negative on average $9.53 \pm 5.85$ days following the follow-up and treatment of the patients. When the patients were evaluated in terms of the units they work,it is noteworthy that 14 (46.7\%) of them were working in the cleaning services.

Only 2 of the patients had comorbidities. Both of these two patients had hypertension. When the medical histories of all patients were examined, it was observed that 3 had a history of allergy. As for the habits, 10 patients were smoking. When the COVID-19-related family histories of the patients were questioned, it was revealed that I6 $(53.3 \%)$ of the patients had a first-degree relative with a history of COVID- 19 infection, and 2 had lost a first-degree relative due to the COVID- 19.

Two patients were admitted to the pandemic ward of the hospital. Other patients were followed-up and treated at home under isolation. Typical involvement for COVID-19 was observed on thoracic computed tomography (CT) of one of the hospitalized patients (Fig. I). However, no sign of COVID-19 pneumonia was detected in the CT images of the other patients. No patient was followed in the intensive care unit. No mortality occurred in these healthcare workers.

The one-month period before vaccination (from December 14, 2020 to January 14, 202 I) was analysed to compare the COVID-19 infection status of the healthcare workers, and it was found that 125 (2.9\%) healthcare workers was infected with COVID-19 in this one month.

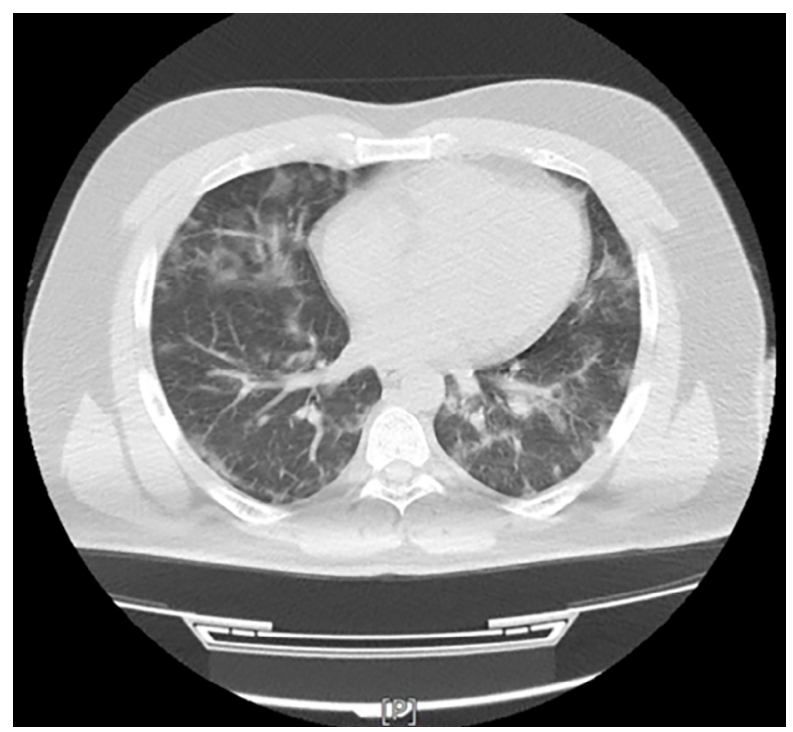

Figure 1. Chest CT scan showing pulmonary lesions typical for COVID-19. 


\section{DISCUSSION}

Healthcare workers are at high risk in the COVID-19 pandemic due to close contact in their working environment. That is the reason priority was given to healthcare workers in vaccination campaigns. In the one month period between the first and second doses of the vaccine, cases of COVID- 19 were seen among those vaccinated. The emergence of such cases after the first dose of vaccine suggests the need for a second dose of the vaccine.

Vaccines are considered the most promising approach to contain the pandemic. Some of the available vaccines are inactivated virus vaccines, some are vaccines using recombinant proteins and vectors, and some are RNA/DNA vaccines, and each country has granted emergency use authorization to these vaccines in line with their own health management systems. ${ }^{\left[{ }^{I I]}\right.}$

The efficacy of CoronaVac, an inactivated virus vaccine, has been reported as $91.25 \%$ in Turkey. ${ }^{[12]}$ On January 13 , 2021 , the vaccine was authorized for emergency use in Turkey and the first dose of the vaccine was administered to the Minister of Health of the country. Then, a rapid vaccination campaign was launched across the country, primarily to vaccinate healthcare workers.

In this study, we examined the data of 3,259 healthcare workers vaccinated in a large city hospital in Turkey on January 14, 202I, and found that 30 of these HCWs had PCR-confirmed COVID-19 infection after getting vaccinated. Although it is significant that approximately I out of every 100 vaccinated healthcare workers were infected with COVID-I9 infection, it is an important finding that there was no mortality or need for intensive care unit admission in these patients.

Recently, the Pfizer-BioNTech (BNTI62b2; Pfizer Inc.) COVID-I9 vaccine was administered to 4,08 I healthcare workers in a large hospital in Israel, and 22 of these healthcare workers were reported to have tested positive for COVID-19. The authors emphasized that during a largescale vaccination campaign that coincided with the rapid increase in national COVID-19 cases, it was possible for some vaccinated individuals to develop the clinical disease.

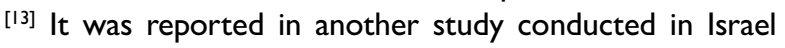
that the incidence of COVID-19 infection was lower in vaccinated healthcare workers compared to those who were not vaccinated. ${ }^{[14]}$ In our study, the number of the healthcare workers infected with COVID-19 in the month before vaccination was 125 , whereas the number of healthcare workers who contracted COVID-19 in the month following the first dose of vaccination was 30 , which supports that vaccination elicits an immune response to the disease.

On the other hand, with the use of the vaccine, a false sense of safety can occur in individuals and as a result, they may be a rapid increase in the number of COVID-19 cases. Such a false sense of safety may lead to decreased social distancing and personal protection especially in the period when people are already fed up with the constant security measures, testing, isolation and restrictions. For this reason, it should be paid attention to whether there is a new COVID- 19 infection in all kinds of physical complaints that appear after vaccination.

\section{CONCLUSION}

Undetected cases of COVID-19, especially among healthcare workers, can be dangerous to patients and other healthcare workers. It should be always kept in mind that even if they are vaccinated, healthcare workers can be infected with COVID-19, and thus, they should maintain personal protective measures in the fight against the disease. COVID-1 9 cases seen after the first dose of vaccine indicate the need for a second dose of vaccine.

\section{Ethics Committee Approval}

This study approved by the Kartal Dr. Lutfi Kirdar City Hospital Clinical Research Ethics Committee (Date: 24.02.2021, Decision No: 514/196/26).

Informed Consent

Retrospective study.

Peer-review

Internally peer-reviewed.

Authorship Contributions

Concept: R.D.; Design: R.D.; Supervision: E.Y.; Fundings: E.Y.; Materials: E.Y.; Data: E.Y., M.M.A., A.B.; Analysis: E.Y., N.M.H., R.A.; Literature search: E.Y., N.M.H., R.A.; Writing: R.A., M.M.A., A.B.; Critical revision: E.Y., M.M.A., A.B.

Conflict of Interest

None declared.

\section{REFERENCES}

1. Doğanay F, Elkonca F, Seyhan AU, Yllmaz E, Batırel A, Ak R. Shock index as a predictor of mortality among the Covid-19 patients. Am J Emerg Med 2021;40:106-9. [CrossRef]

2. Ak R, Yilmaz E, Seyhan AU, Doganay F. Recurrence of COVID-19 documented with RT-PCR. J Coll Physicians Surg Pak 2021;30:268. [CrossRef]

3. WHO. Coronavirus dashboard. Available at: https://covid19.who. int/. Accessed Aug 4, 2021.

4. Flaxman S, Mishra S, Gandy A. Estimating the effects of nonpharmaceutical interventions on COVID-19 in Europe. Nature 2020;584:257-61. [CrossRef]

5. Sanche S, Lin YT, Xu C, Romero-Severson E, Hengartner N, Ke R. High contagiousness and rapid spread of severe acute respiratory syndrome coronavirus 2. Emerg Infect Dis. 2020;26:1470-7. [CrossRef]

6. WHO. Draft landscape of COVID-19 candidate vaccines. Available at: https://www.who.int/publications/m/item/draft-landscape-ofcovid-19-candidate-vaccines. Accessed Oct 20, 2020.

7. Dooling K, McClung N, Chamberland M, Marin M, Wallace M, Bell BP, et al. The Advisory Committee on Immunization Practices' interim recommendation for allocating initial supplies of COVID-19 vaccine - United States, 2020. MMWR Morb Mortal Wkly Rep 2020;69:1857-19. [CrossRef]

8. Wu Z, Hu Y, Xu M, Chen Z, Yang W, Jiang Z, et al. Safety, tolerability, and immunogenicity of an inactivated SARS-CoV-2 vaccine 
(Corona Vac) in healthy adults aged 60 years and older: a randomised, double-blind, placebo-controlled, phase $1 / 2$ clinical trial. Lancet Infect Dis 2021;21:803-12. [CrossRef]

9. Palacios R, Patiño EG, de Oliveira Piorelli R, Conde MTRP, Batista AP, Zeng G, et al. Double-blind, randomized, placebo-controlled phase III clinical trial to evaluate the efficacy and safety of treating healthcare professionals with the adsorbed COVID-19 (inactivated) vaccine manufactured by Sinovac - PROFISCOV: A structured summary of a study protocol for a randomised controlled trial. Trials 2020;21:853. [CrossRef]

10. Seyhan AU, Doğanay F, Yllmaz E, Aydıner Ö, Ak R, Tekol SD. The comparison of chest $\mathrm{CT}$ and RT-PCR during the diagnosis of COVID-19. J Clin Med Kaz 2021;18:53-6. [CrossRef]
11. Zhou P, Li Z, Xie L, An D, Fan Y, Wang X, et al. Research progress and challenges to coronavirus vaccine development. J Med Virol 2021;93:741-54. [CrossRef]

12. Reuters. Turkey says China's Sinovac COVID vaccine $91.25 \%$ effective in late trials. Available at: https://www.reuters.com/article/ health-coronavirus-turkey-chinaint-idUSKBN28Y1R3. Accessed Dec 28, 2020.

13. Amit S, Beni SA, Biber A, Grinberg A, Leshem E, Regev-Yochay G. Postvaccination COVID-19 among Healthcare Workers, Israel. Emerg Infect Dis 2021;27:1220-2. [CrossRef]

14. Amit S, Regev-Yochay G, Afek A, Kreiss Y, Leshem E. Early rate reductions of SARS-CoV-2 infection and COVID-19 in BNT162b2 vaccine recipients. Lancet 2021;397:875-7. [CrossRef]

\section{Birinci Doz Coronavirus Aşısı Olduktan Sonra COVID-19 Enfeksiyonu Görülen Sağlık Çalışanlarının Özellikleri}

Amaç: Sağlık çalışanları COVID-19 enfeksiyonu için yüksek risk altındadır. Dünyanın birçok ülkesinde olduğu gibi Türkiye'de de aşılama için sağılık çalışanlarına öncelik verildi. Bu çalışmadaki amacımız Hastanemizde Coronovac aşısının ilk dozunu olduktan sonra COVID-19 enfeksiyonu görülen sağlık çalışanlarının incelenmesidir.

Gereç ve Yöntem: Bu geriye dönük gözlemsel çalışmada, I4 Ocak 202I tarihinde hastanemizde çalışan sağlık personellerine Coronavac aşısının ilk dozu uygulanmıştır. Çalışmaya aşı sonrası bir aylık dönemde RT-PCR testi ile konfirme edilen COVID-19 enfeksiyonu görülen her iki cinsiyetteki sağlık çalışanlarının tümü dahil edilmiştir. Bu hastaların genel demografik ve klinik verileri hastanenin elektronik hasta kayıt yönetim sistemi (HBYS) kullanılarak taranmıştır.

Bulgular: Hastanemizde 4.195 sağıı çalışanı bulunmaktadır. Bunların 3.259'una (\%77.68) Coronavac aşısının ilk dozu uygulanmıştır. Tanı alan sağılı personellerinin I7'si (\%56.7) kadın, I3'ü (\%43.3) erkek cinsiyetinde olup ortalama yaşları $38.96 \pm$ I I.23 olarak saptandı. İki hastanın pandemi servisinde yatışı gerçekleşti. Hastaların hiçbirinde mortalite veya yoğun bakım yatış ihtiyacı görülmedi.

Sonuç: Özellikle sağık çalışanları arasında tespit edilmemiş COVID-19 olguları hastalar ve diğer personel için tehlikeli olabilir. Bu nedenle sağıı çalışanlarının tamamının aşılanması hedeflenmelidir. Aşılansa bile COVID-I 9 enfeksiyonu geçirebileceklerini unutmamalı, hastalıkla mücadelede kişisel koruyucu önlemlerini almaya devam etmelidir. İlk doz aşıdan sonra görülen COVID-19 olguları, ikinci doz aşının gerekliliğini göstermektedir.

Anahtar Sözcükler: Aşı; aşılama; CoronaVac; COVID-19; sağlık çalışanları. 